\title{
Averaged Vibration Levels During Courier Parcel Delivery Service in Small Truck in Hungary
}

Péter Böröcz

Associate Professor Department of Logistics and Forwarding Széchenyi István University, Győr Hungary

In recent years there continues to be an increase in courier parcel delivery services due to the growing global online economy and express parcel shipments. It is therefore important to measure and quantify the levels of vibration that occur inside the vehicle during transport, as it can be one of the primary sources of damages. The purpose of this study was to measure the averaged vibration levels in vertical, lateral and longitudinal directions that occur in courier delivery shipments from pickup to delivery involving small trucks over ground road transportation in Hungary. The recorded acceleration data were analyzed in terms of power spectral densities (PSD) and presented with overall $G_{r m s}$. The results of the separated afnd averaged vibration levels provide physical circumstances for various road and load conditions showing those frequency bands that have significant intensities.

Keywords: vibration; PSD; small truck; packaging; parcel delivery

\section{INTRODUCTION}

Small truck transportation is used worldwide for distribution of small quantities of goods and mostly single and lightweight parcel packages for trade. Although it is relatively expensive compared to mid-sized and heavy truck transportation, it is often the most economical way to provide parcel courier services in places where inexpensive or other forms of distribution alternatives are not available. Furthermore, the global online economy is increasingly demanding that single parcels and products be distributed on a worldwide basis.

During transportation one of the primary sources of damages to products and packages can be attributed to the various vibration forces that occur in a vehicle [1]. Previous studies have been done to measure and analyse these vibration levels but were limited mainly to heavy truck trailers and these investigations usually consisted of a small section of road trips [2,3]. The speed of vehicle, the type of suspension system and tires used and its stiffness and damping, the load capacity, the road conditions, as well as the vehicle's general conditions can affect the vibration during transport [4-8].

The aim of this study is to gather data over a large section of the Hungarian highway network using 5 commercially available small trucks. The focus of this study was to analyse the vibration levels during daily parcel delivery service. The results present power spectral density (PSD) plots for the total number of recorded acceleration values, and for the top 5\% and $20 \%$ highest values, and for the bottom $80 \%$ of the total, respectively. These conditions allow for the development of methods that can simulate these transport environments

Received: November 2017, Accepted: December 2017 Correspondence to: Péter Böröcz, Ph.D.

Széchenyi István University, Department of Logistics and Forwarding, Győr, Hungary

E-mail: boroczp@sze.hu

doi:10.5937/fmet1802211B

(C) Faculty of Mechanical Engineering, Belgrade. All rights reserved in the laboratory.

Shipments from three different courier operators were instrumented with tri-axial accelerometer to measure the vibration levels in all three orientations. The data was collected for various route, load and vehicle speed conditions.

\section{ROAD NETWORK AND SMALL TRUCKS IN HUNGARY}

Hungary has an extensive road network that originates from the capital Budapest. The total road network in Hungary in 2013 accounts for approximately 203,309 $\mathrm{km}$ and it is the fourth densest in the EU-28 [9].

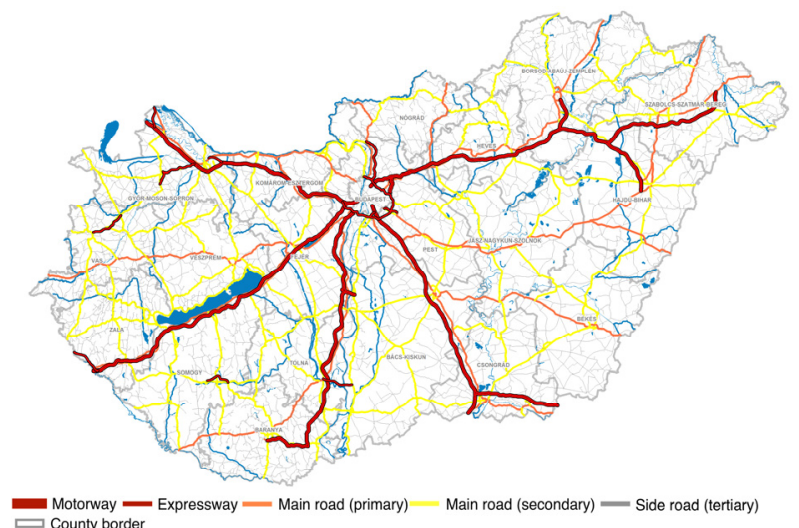

Figure 1. Map of Hungarian road transportation route network (source: GeoX Kft.)

The road network (Figure 1) can be divided into two major categories: the national highways $(31,663 \mathrm{~km}$ [9]) and municipal roadways. Concrete national roads constitute almost $99.9 \%$ of the total number of roads. The national road network can be further divided into two major subcategories such as the main roads consisting of motorways, express roads, first-class and second-class roads and minor (or secondary) roads. 
Table 1 contains data for the road network length per category and the number of trucks registered according to their gross vehicle weight (GVW) in 2013 in Hungary. In 2013, the total number of registered general trucks in Hungary was 401,723 [9]. For pick-up and delivery of relatively light loads and packages small trucks with a maximum possible payload of t.5 tons are the most popular vehicles (GVW 3.5 ton). The total road transport in 2013 in Hungary was 35.8 billion tkm [10]. The average transport distance for inner city and regional delivery was about $70 \mathrm{~km}$ and appro-ximately $720 \mathrm{~km}$ for national distribution.

\section{INSTRUMENTATION AND ANALYSIS}

\subsection{Measuring device and setup}

The vibration events during courier parcel delivery routes were measured for all three axes (vertical, lateral and longitudinal) using Lansmont (SAVER) ${ }^{\mathrm{TM}} 3 \mathrm{X} 90$ (Shock and Vibration Environment Recorder, Lansmont Corp., CA, USA) to collect the data. Then Saver XwareTM software and MathLab R2014a software were also used to analyse the data.

For each segment of the measurement the recorder was mounted directly to the floor and was located at the right rear of the vehicle cargo area. In those cases when the container floor was wooden the SAVER was fixed by screws, and when it was metal the SAVER was fixed with a magnetic kit. These can be seen in Figure $2 a$ and $2 b$.

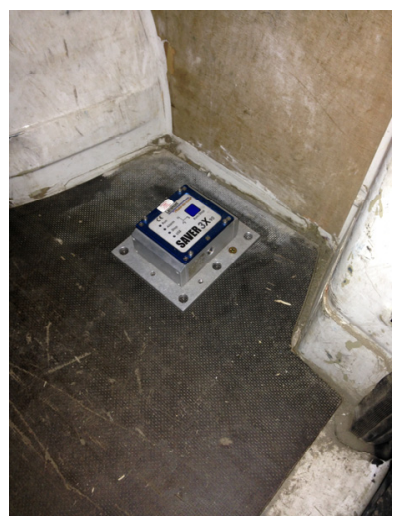

a)

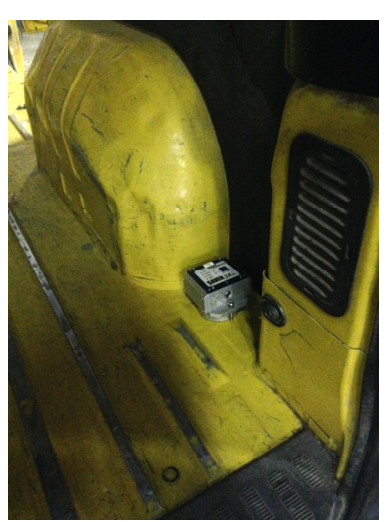

b)
Figure 2. SAVER in small trucks fixed with screws (a), and with magnetic kit (b)

Table 1. National road and truck data in Hungary for 2013 [10]
The settings of the recorder used in this study are shown below, and can be seen in Figure 3.

- Timer trigger: $30 \mathrm{~s}$

- $\quad$ Signal trigger: $2.5 \mathrm{G}$

- $\quad$ Recording Time: $2.048 \mathrm{~s}$

- Sample/sec: $500 \mathrm{~Hz}$, sample size: 1024

- Frequency resolution for PSD: $0.488 \mathrm{~Hz}$

- Anti-aliasing filter frequency: $250 \mathrm{~Hz}$

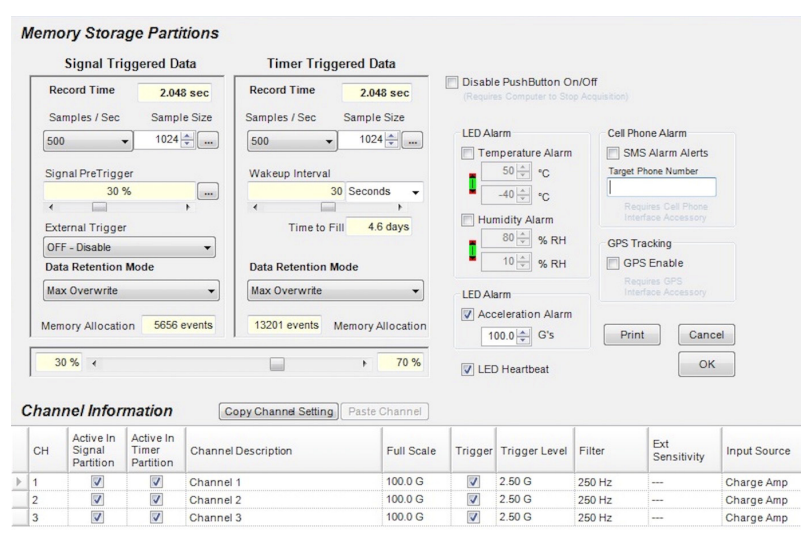

Figure 3. Setting the parameters of the SAVER data logger used for this study

\subsection{Measuring circumstances}

In order to analyse the averaged vibration levels from multiple vehicles five different small trucks were used by three different carriers (TNT, DHL and UPS). Each vehicle was monitored for approximately 8 hours of a total workday trip and the total duration the trucks were in motion was between 5.5-6.5 hours. The entire measuring time was from Monday to Friday. The measurements were conducted with various payloads and speeds in the range of $0-1340 \mathrm{~kg}$ to $1-130 \mathrm{~km} / \mathrm{h}$. The payload condition during shipping varied for the packages being delivered and picked up. The suspension system of all observed small trucks was a parabolic leaf spring at the rear axle.

To determine the averaged effect of the circumstances of transportation such as road condition during shipping, the small trucks travelled on various roads, such as motorways, primary roads, secondary roads, tertiary roads and city roads.

\begin{tabular}{|l|c|l|l|c|}
\hline \multicolumn{1}{|c|}{ Road category } & $\begin{array}{c}\text { Length } \\
(\mathbf{k m})\end{array}$ & & Truck category & $\begin{array}{c}\text { Quantity } \\
\text { (pcs) }\end{array}$ \\
\hline Major network & $\underline{8361}$ & & General trucks & $\underline{401723}$ \\
\hline - Motorway road & 1336 & & $-3.49 \mathrm{t}$ & 280390 \\
- First Class road & 2147 & & $3.5-7.49 \mathrm{t}$ & 85640 \\
- Second Class road & 4878 & & $7.5-11.49 \mathrm{t}$ & 13029 \\
Minor network & $\underline{23399}$ & & $12 \mathrm{t}-$ & 22664 \\
- Connecting road & 18197 & & \\
- Access road & 4556 & & & \\
- Other road & 646 & & & \\
Municipal & $\underline{171549}$ & & & \\
\hline Total & $\mathbf{2 0 3 ~ 3 0 9}$ & & & \\
& & & \\
\hline
\end{tabular}


Obviously these trips depended on the daily route program of the courier company. The geographical locations of these measurements were as follows: county of Győr-Moson-Sopron (GYMS, Veszprém (V) and Komárom-Esztergom (KE).

Table 2 contains the specifications of the vehicles used in this study and Table 3 contains the details of those road conditions connected to the daily trips.

\subsection{Data analyst}

In the case of vibration analysis power density (PD) levels were determined as a function of frequency based on the recorded random vibration acceleration levels as used former researches [11] [12].

The average power density within a narrow band of frequencies (BW) of a given spectrum can be determined by $G_{r m s}$ values based on the number of samples of a given bandwidth. In this way $\mathrm{G}_{\mathrm{rms}}$ is determined by the root mean square value of the acceleration in G's in the given bandwidth of frequency, based on the number of (n) samples.

$$
P D=\frac{1}{B W} \sum_{i=1}^{n}\left(R M S G_{i}^{2}\right) / n
$$

The vibration environment was then represented by the power density spectrum (PSD) showing a plot of the power density levels versus frequency. The energy within a specific frequency range can be obtained by integrating PSD within that frequency range and is usually represented in $G_{\mathrm{rms}}$ for the entire or portion of the spectrum. The computation of PSD is done directly using the method called Fourier transformation or computing autocorrelation function and then transforming it to use as diagnostic method [13] [14]. Figure 4 shows an example of a PSD lot for normal truck transportation with leaf spring suspension [15].

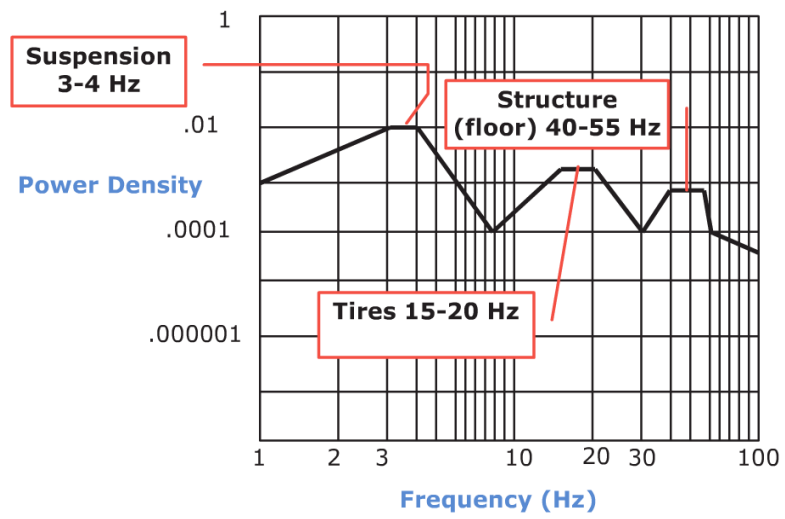

Figure 4. Typical PSD plot for heavy truck vibration [15]

In this study the data are presented and analysed from 1 to $200 \mathrm{~Hz}$. First, the recorded vibration data were filtered to remove all undesirable events such as any noise or non-vibration featured movements from the analysis, i.e. stopovers that occur during daily transportations. So according to this data below $0.02 \mathrm{G}_{\mathrm{rms}}$ were filtered out.

This method was already used previously by the author [16] and other prior published researchers who removed inactive segments from the measured records [17] [18].

Table 2. Specifications of small trucks and details of daily trips for this study

\begin{tabular}{|c|c|c|c|c|c|c|c|}
\hline & 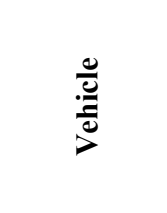 & 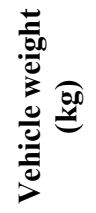 & 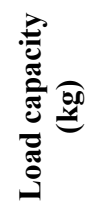 & 离 & 递 & 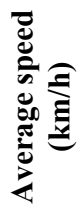 & 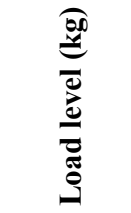 \\
\hline \multirow{5}{*}{$\begin{array}{l}\text { Monday } \\
\text { Tuesday } \\
\text { Wednesday } \\
\text { Thursday } \\
\text { Friday }\end{array}$} & Fiat Ducato & 1935 & 1165 & 8.0 & 3000 & 53.7 & $110-400$ \\
\hline & Fiat Ducato & 1975 & 1525 & 13.0 & 4035 & 47.8 & $35-880$ \\
\hline & Fiat Ducato & 2010 & 1490 & 14.8 & 4332 & 31.2 & $0-440$ \\
\hline & Ren. Master & 1811 & 1489 & 8.0 & 3182 & 40.8 & $10-530$ \\
\hline & Ford Transit & 2018 & 1482 & 15.1 & 3750 & 45.6 & $180-1340$ \\
\hline
\end{tabular}

Table 3. Details of road condition details of the daily trips used in this study

\begin{tabular}{|c|c|c|c|c|c|c|}
\hline & 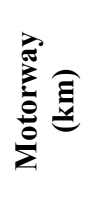 & 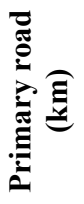 & 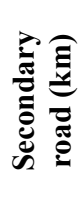 & 㺼 & 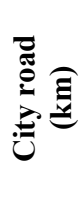 & 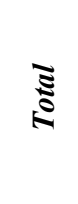 \\
\hline \multirow{5}{*}{$\begin{array}{l}\text { Monday } \\
\text { Tuesday } \\
\text { Wednesday } \\
\text { Thursday } \\
\text { Friday }\end{array}$} & 41 & 13 & 14 & 37 & 53 & 158 \\
\hline & 55 & 69 & 67 & 31 & 66 & 288 \\
\hline & 0 & 131 & 87 & 81 & 38 & 337 \\
\hline & 27 & 103 & 63 & 61 & 72 & 326 \\
\hline & 7 & 67 & 66 & 47 & 87 & 274 \\
\hline Total & 130 & 383 & 297 & 257 & 316 & 1383 \\
\hline
\end{tabular}


The PSDs were then created using the remaining measured data in which a spectrum for the top 5 and 20 percent of the highest measured data are shown, followed by a lower spectrum representing the remainder 80 percent of all recorded data. Therefore spectrums are presented for the top 5 and top 20 percent of saved events and 80 percent of remaining events, as shown in previous studies [15] [19] [20]. In addition a spectrum representing the average for $100 \%$ of all events measured is also presented. Finally the PSD plots of signal and timer triggered events are also shown separately [21]. Power density spectrums in all three directions (vertical, lateral and longitudinal) are presented in this paper and each PSD is reported with an Overall $\mathrm{G}_{\mathrm{rms}}$.

The reason for combining the various trips into one power spectral density (PSD) plot is that the measured small trucks (FIAT Ducato, FORD Transit and RENAULT Master) practically have the same vehicle body and structure, and so the statistical validity of vibration levels for vans could be averaged to represent the slight variation among trips [15] [16] [20].

\subsection{Statistical analysis}

Statistical analysis was conducted on the absolute peak acceleration values recorded for the five trips to determine cumulative distribution functions (CDF) using the Weibull two-parameter distribution model, for all three axes separately.

Here, it has to be mentioned that there was no particular reason for choosing the Weibull distribution; simply this distribution model was determined to be the best fit to the data. The Weibull distribution is widely used in reliability engineering due to its relative simplicity. Its CDF has two parameters, presented in equation (2), as follows: $>0$ is the scale parameter, $>0$ is the shape parameter.

$$
F(x \mid \alpha, \beta)=\int_{0}^{x} \beta \alpha^{-\beta} t^{\beta-1} e^{-(t / \alpha)}{ }^{\beta} d t=1-e^{-(x / \alpha)^{\beta}}
$$

\section{RESULTS}

\subsection{Empirical acceleration data}

Table 4 contains data regarding numbers of samples used to analyse the entire shipping section to create PSD plots. The total number of events recorded before filtering was 4349. Figure 5 shows all recorded and filtered dynamic acceleration levels of the resultant direction in $\mathrm{G}_{\mathrm{rms}}$. These events (over or equal to 0.02 $\mathrm{G}_{\mathrm{rms}}$ ) are represented in the time history domain.

As it was already mentioned above that circumstance such as road conditions can affect the vibration levels. These differences can be seen in Figure 4 in the form of RMS acceleration. Those days when the truck travelled relatively more with bad road conditions the vibration levels were more severe. This was the situation from Wednesday to Friday when the truck predominantly travelled on tertiary and city roads.

Figure 6 shows the CDFs for the measured peak acceleration values in all three axes and the RMS values for the resultant acceleration. The CDFs show the percentage of the events that are below a certain level of the measured peak acceleration value. It can be seen that the acceleration values in the longitudinal direction were generally lower than those of the lateral. The highest acceleration values in this study were in the vertical axis. Tables 5 and 6 contain the statistical parameters of these distributions that use recorded acceleration data and are based on best-fit regression analysis.

Table 4. Number of samples for developing PSD

\begin{tabular}{|l|c|c|}
\hline Events & \multicolumn{1}{|c|}{$\begin{array}{c}\text { Filter level } \\
\text { by RMS }\end{array}$} & $\begin{array}{c}\text { Filtered } \\
\text { events }\end{array}$ \\
\hline Top 5\% & $>0.586$ RMS & 154 \\
\cline { 2 - 3 } Top 20\% & $0.586 \geq$ RMS $>0.401$ & 624 \\
\cline { 2 - 3 } Bottom $80 \%$ & $0.401 \geq$ RMS $>0.020$ & 2406 \\
\hline Signal tr. part & $\geq 0.020$ RMS & 753 \\
\cline { 2 - 3 } Timer tr. part & $\geq 0.020$ RMS & 2331 \\
\hline Total 100\% & $\geq 0.020$ RMS & 3084 \\
\hline
\end{tabular}

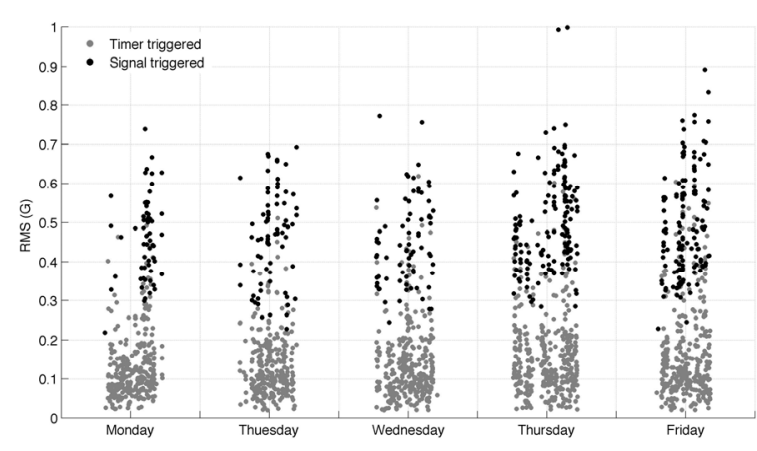

Figure 5. Vibration events recorded in the truck container in RMS (G) (resultant direction)

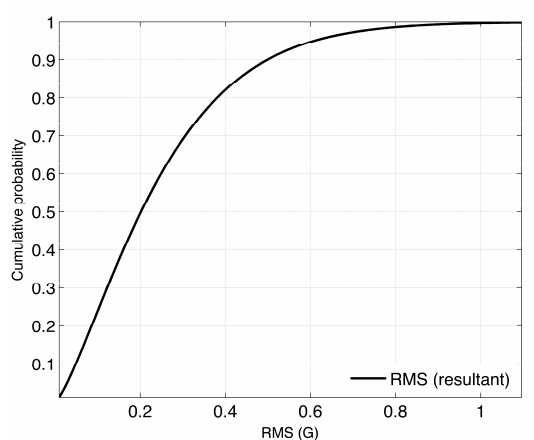

a)

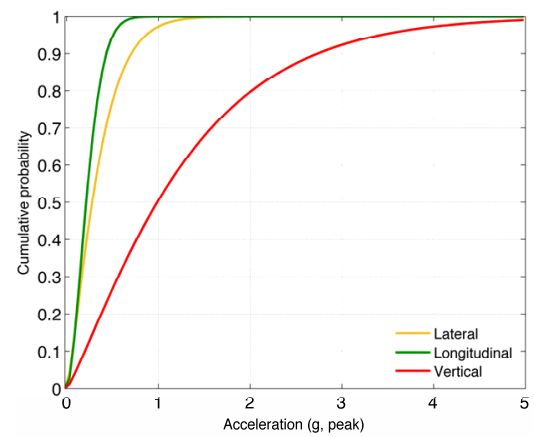

b)

Figure 6. CDFs of RMS accelerations (a) acceleration peaks in vertical, lateral and longitudinal directions (b) for small truck 
Table 5. Summary of empirical acceleration data measured

\begin{tabular}{|l|c|c|c|c|}
\hline & \multicolumn{2}{|c}{$\begin{array}{c}\text { Resultant } \\
(\mathrm{RMS})\end{array}$} & \multicolumn{1}{c}{$\begin{array}{c}\text { Vertical } \\
\text { (g, peak) }\end{array}$} & \multicolumn{2}{c}{$\begin{array}{c}\text { Lateral } \\
(\mathrm{g}, \text { peak })\end{array}$} & $\begin{array}{c}\text { Longitudinal } \\
\text { (g, peak) }\end{array}$ \\
\hline \multirow{2}{*}{ Max. } & 1.09 & 4.93 & 2.55 & 1.64 \\
\cline { 2 - 5 } At 99\% occurrence & 0.74 & 4.02 & 1.09 & 0.76 \\
\cline { 2 - 5 } At 95\% occurrence & 0.62 & 3.26 & 0.86 & 0.52 \\
\cline { 2 - 5 } At 90\% occurrence & 0.54 & 2.96 & 0.76 & 0.43 \\
\cline { 2 - 5 } Mean & 0.24 & 1.26 & 0.33 & 0.23 \\
\hline
\end{tabular}

Table 6. Statistical parameters of distribution based on best-fit regression analysis

\begin{tabular}{|l|c|c|c|c|c|c|}
\hline & $\begin{array}{c}\text { Predicted } \\
\text { Mean }\end{array}$ & \multicolumn{2}{c}{ Variance } & \multicolumn{2}{c}{ Estimate $\alpha$} & \multicolumn{2}{c|}{ Estimate $\beta$} & \multicolumn{2}{c|}{ R-square } & \multirow{2}{*}{ RMSE } \\
\hline RMS & 0.24 & 0.03 & 0.26 & 1.32 & 0.914 & 0.05 \\
\cline { 2 - 7 } Vertical & 1.27 & 1.19 & 1.34 & 1.17 & 0.946 & 0.09 \\
\cline { 2 - 7 } Lateral & 0.34 & 0.07 & 0.36 & 1.28 & 0.885 & 0.06 \\
\cline { 2 - 7 } Longitudinal & 0.24 & 0.02 & 0.26 & 1.69 & 0.901 & 0.04 \\
\hline
\end{tabular}

\subsection{Power Spectral Density (PSD)}

The data was further analysed in the form of Power Density Spectrums for all three orientations (vertical, lateral and longitudinal).

The data are presented in vibration spectrums developed for the all trips based on total recorded events and also spectrums for the top $5 \%$ and $20 \%$ most severe events and the bottom $80 \%$ of the remaining events; this can be seen in Figure 7-9.

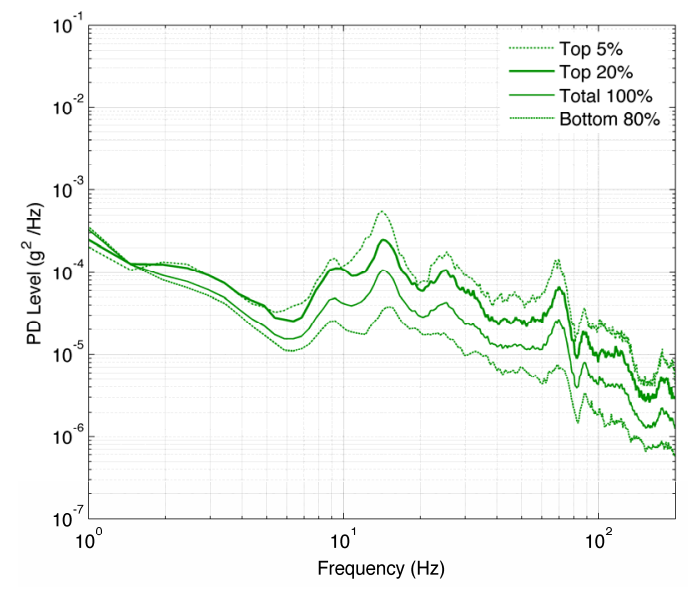

Figure 7. Longitudinal power density spectrums based on the highest $5 \%$, highest $20 \%$, bottom $80 \%$ and the average of all events

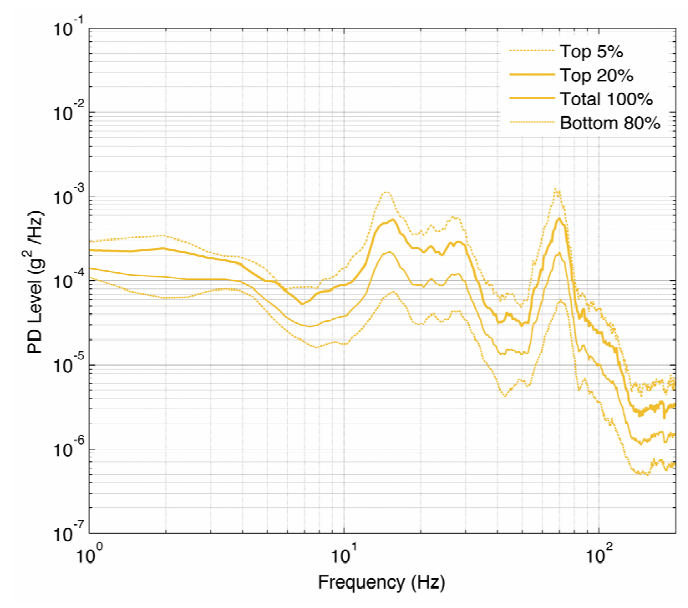

Figure 8. Lateral power density spectrums based on the highest $5 \%$, highest $20 \%$, bottom $80 \%$ and the average of all events

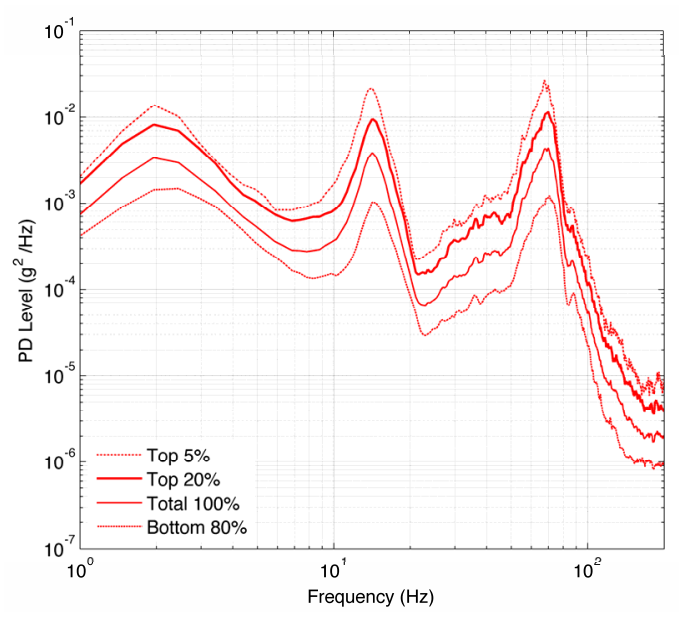

Figure 9. Vertical power density spectrums based on the highest $5 \%$, highest $20 \%$, bottom $80 \%$ and the average of all events

It is clearly visible that the highest vibration levels occur in the vertical direction around $2 \mathrm{~Hz}, 15 \mathrm{~Hz}$ and then $70 \mathrm{~Hz}$, respectively. The PSD plots show that the vibration levels were the highest in the vertical axis. However, in the frequency range between 20 and $30 \mathrm{~Hz}$ the lateral vibration levels slightly exceeded those in the vertical orientation. Overall lateral vibration levels were generally higher than the longitudinal vibration levels. Over $100 \mathrm{~Hz}$, in the higher frequency regions, the PD levels decreased rapidly in all three orientations.

In addition, Figure 10 contains PSD spectra separately for signal and timer triggered events of all recorded data. These are for information only because these events represent approximately $25 \%$ or $75 \%$ of all data covered, and the signal part shows only events above the threshold limit of $2.5 \mathrm{G}$. Table 7 reports the overall $G_{\mathrm{rms}}$ values of recorded vibration events for the various routes in all three axes.

Table 7. Overall $G_{r m s}$ in the frequency bandwidth of $1-200 ~ H z$

\begin{tabular}{|l|c|c|c|}
\hline Events & \multicolumn{1}{|c|}{ Vertical } & \multicolumn{1}{c|}{ Lateral } & \multicolumn{1}{c|}{ Longitudinal } \\
\hline Top 5\% & 0.675 & 0.176 & 0.098 \\
\cline { 2 - 4 } Top $20 \%$ & 0.487 & 0.130 & 0.098 \\
\cline { 2 - 4 } Total $100 \%$ & 0.310 & 0.084 & 0.055 \\
\cline { 2 - 4 } Bottom 80\% & 0.178 & 0.052 & 0.043 \\
\cline { 2 - 4 } Signal t. & 0.533 & 0.141 & 0.081 \\
\cline { 2 - 4 } Timer t. & 0.189 & 0.055 & 0.044 \\
\hline
\end{tabular}




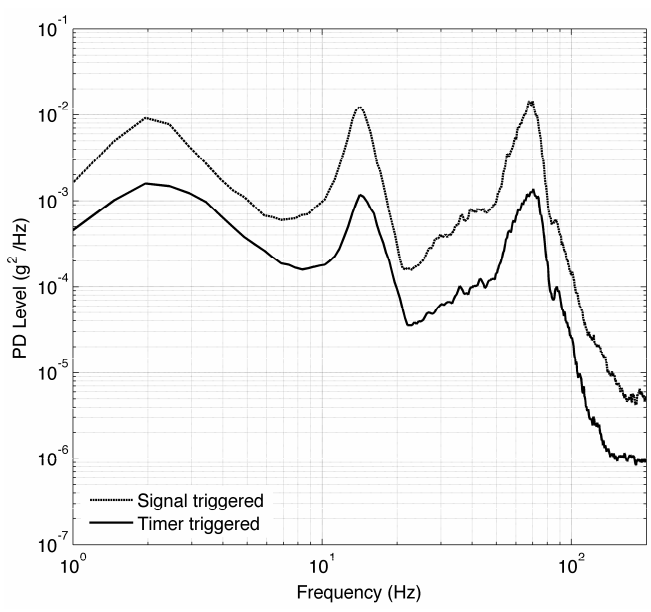

Figure 10. Vertical power density spectrums based on signal and timer triggered events

\subsection{Limitations of the study}

The author of this paper wants to call attention to the fact that the method of PSD involves the use of the Fast Fourier Transformation (FFT) process and due to this this it produces a PSD profile with average intensity of the vibration over the frequency range of interest [18].

Furthermore, the use of presented PD levels as vibration simulation conditions does not expose the test items to extreme levels of vibration or transients like shock events, which can occur during real transportation.

\section{CONCLUSION}

The following conclusions can be drawn from the results of this study:

- The highest dynamic vibration levels in small trucks occur in the vertical direction, followed by lateral and then longitudinal direction, respectively.

- The most intensive vibrations can be found at around $2 \mathrm{~Hz}, 15 \mathrm{~Hz}$ and $70 \mathrm{~Hz}$.

- Over $100 \mathrm{~Hz}$ the PD levels decrease rapidly in all three orientations.

- The presented PD spectrums based on the measured data from this study can be used as test circumstances for vibration simulations in small trucks during courier parcel shipments with different severity.

\section{ACKNOWLEDGMENT}

This work was supported by the project EFOP-3.6.116-2016-00017 of Széchenyi István University. The author would also like to acknowledge the companies and partners (TNT Hungary Kft., DHL Hungary Kft. and UPS Hungary Kft) that allowed the measurements to be taken in their shipping environment.

\section{REFERENCES}

[1] Yam, KL.: Encyclopedia of Packaging Technology, John Wiley \& Sons Inc.: Hoboken, New Jersey, USA, 2009
[2] Singh, S.P., Jarimopas, B., and Saengnil, W.: Measurement and Analysis of Vibration Levels in Commercial Truck Shipments in Thailand and Its Impact on Packaged Produce, J. Test. Evaluat., Vol., No. 2, pp.1-7, 2006. doi: 10.1520/JTE14007

[3] Chonhenchob, V. and Singh, S.: Testing and Comparison of Various Packages for Mango Distribution, J. Test. Evaluat., Vol. 32, No. 1, pp.1-4, 2004 doi: 10.1520/JTE1 1888

[4] Singh S.P., Marcondes J.: Vibration levels in commercial truck shipments as a function of suspension and payload. J. Test. Evaluat. Vol. 20, No. 6, pp. 466-469, 1992. doi:10.1520/JTE11941J

[5] Fragassa, C. et al.: Measuring the mechanical and climatic conditions encountered by palletized products in handling and transport. FME Transactions, Vol. 45, No. 3, pp. 382-393, 2017. doi: $10.5937 /$ fmet $1703382 \mathrm{~F}$

[6] Singh, J., Singh, S. P. and Joneson, E.: Measurement and analysis of US truck vibration for leaf spring and air ride suspensions, and development of tests to simulate these conditions. Packag. Technol. Sci., Vol. 19, No. 6, pp. 309-323, 2006 doi:10.1002/pts.732

[7] Böröcz, P.: Vibration Levels in Vans as a Function of Payload and Leaf Spring Sheet Number. J. Test. Evaluat., First Look Paper, 2018. doi: 10.1520/JTE20160538

[8] Zhou, R. et al.: Measurement of Truck Transport Vibration Levels in China as a Function of Road Conditions, Truck Speed and Load Level. Packag. Technol. Sci., Vol. 28, No. 11, pp. 949-957, 2015. doi: $10.1002 /$ pts. 2176 .

[9] Hungarian Central Statistics Office. Regional characteristics of the road transporation (A közúti közlekedés területi jellemzői), 2013. http://www .ksh.hu/docs/hun/xftp/idoszaki/regiok/debgyorkoz utikozl.pdf [accessed 30 Sept 2017]

[10]Hungarian Central Statistics Office. State of transport sector in 2013. 2014.dec., http://www .ksh.hu/docs/hun/xftp/idoszaki/jelszall/jelszall13.xl s [accessed 30 Sept 2017]

[11]Ilić, Z., Rašuo, B., Jovanović, M., Janković, D.: Impact of Changing Quality of Air/Fuel Mixture during Flight of a Piston Engine Aircraft with Respect to Vibration low Frequency Spectrum, FME Transactions, Vol. 41 No.1, pp. 25-32, 2013.

[12] Ilić, Z., Rašuo, B., Jovanović, M., Pekmezović, S., Bengin, A., Dinulović, M.: Potential Connections of Cockpit Floor - Seat on Passive Vibration Reduction at Piston Propelled Airplane, Technical Gazette, Vol.21, No.3, pp. 471-478, 2014.

[13] Matijević, D.V., Popović, V.M.: Overview of Modern Contributions in Vehicle Noise and Vibration Refinement with Special Emphasis on Diagnostics, FME Transactions, Vol. 45, No. 3, pp. 448-458. 2017.

[14]Ilić, Z., Rašuo, B., Jovanović, M., Jovičić, S., Tomić, Lj., Janković, D., Petrašinović, D.: The Efficiency of Passive Vibration Damping on the 
Pilot Seat of Piston Propeller Aircraft, Measurement, Vol. 95, pp. 21-32, 2017.

[15] Singh, S. P., Sandhu, A. P. S., Singh, J. and Joneson, E. Measurement and analysis of truck and rail shipping environment in India. Packag. Technol. Sci., Vol. 20, No. 6, pp. 381-392, 2007. doi:10.1002/pts.764

[16] Böröcz, P., and Singh, S. P.: Measurement and Analysis of Vibration Levels in Rail Transport in Central Europe. Packag. Technol. Sci., Vol. 30, No. 8, pp. 361-371, 2017. doi: 10.1002/pts.2225.

[17] Wallin, B.: Developing a Random Vibration Profile Standard. International Safe Transit Association: East Lansing, MI; Paper presented at Dimensions '07, 2007.

[18] Rouillard, V.: Quantifying the Non-stationarity of Vehicle Vibrations with the Run Test. Packag. Technol. Sci., Vol. 27, No. 3, pp. 203-219, 2014. doi:10.1002/pts.2024

[19] Chonhenchob, V., Singh, S. P., Singh, J. J., Sittipod, S., Swasdee, D. and Pratheepthinthong, S.: Measurement and analysis of truck and rail vibration levels in Thailand. Packag. Technol. Sci., Vol. 23, No. 2, pp. 91-100, 2010. doi:10. $1002 /$ pts. 881

[20] Singh, S. P., Saha, K., Singh, J. and Sandhu, A. P. S.: Measurement and Analysis of Vibration and Temperature Levels in Global Intermodal Container Shipments on Truck, Rail and Ship. Packag. Technol. Sci., Vol. 25, No. 3, pp. 149160, 2012. doi:10.1002/pts.968
[21]Böröcz, P., and Singh, S. P.: Measurement and analysis of delivery van vibration levels to simulate package testing for parcel delivery in Hungary., Packag. Technol. Sci., Wiley Online Early View, 2017. doi: 10.1002/pts.2327

\section{ПРОСЕЧАН НИВО ВИБРАЦИЈА КОД МАЛИХ КАМИОНА КУРИРСКЕ СЛУЖБЕ ЗА ИСПОРУКУ ПОШИЉКИ НА ТЕРИТОРИЈИ МАЂАРСКЕ}

\section{П. Берец}

У новије време активности службе за испоруку пошиљки су све интензивније због развоја глобалне online економије и експресне отпреме пошиљки. Зато је важно измерити и квантификовати ниво вибрација које настају у возилу за време транспорта, јер оне могу бити један од главних узрока оштећења. Циљ рада је био да се измери просечан ниво вибрација у вертикалном, латералном и лонгитуffдиналном правцу у малом возилу, од тренутка подизања до испоруке пошиљке од стране курирске службе, у друмском превозу на територији Мађарске. Подаци о забележеном убрзању су анализирани са аспекта спектралне густине снаге (PSD) и приказани укупним $\mathrm{G}_{\mathrm{rms}}$. Резултати појединачних и просечних нивоа вибрација приказују физичке околности различитих услова друма и оптерећења који показују фреквенцијске појасеве који имају значајан интензитет. 